\title{
Accessory soleus muscle: a case report and clinical applicability
}

\author{
William Paganini Mayere, , Josemberg da Silva Baptistaa, \\ Rogério Albuquerque Azeredo ${ }^{\mathrm{a}, \mathrm{b}}$, Fernando Musso ${ }^{\mathrm{b}}$
}

Mayer WP, Baptista JS, Azeredo RA, Musso F. Accessory soleus muscle: a case report and clinical applicability. Autopsy Case Rep [Internet]. 2013; 3(3): 5-9. http://dx.doi.org/10.4322/acr.2013.025

\section{ABSTRACT}

\begin{abstract}
Variations in leg muscle are uncommon. Literature on this subject is scarce, but when those variations are reported they may cause alterations in joint mechanics or cause some discomfort in the leg and foot. The accessory soleus muscle (ASM) is considered an unusual anatomical variation, with an incidence of $0.5-6.0 \%$ in the population through studies in cadavers. During routine preparation of study material in the dissection room of the anatomy laboratory of the Escola Superior de Ciências da Santa Casa de Misericórdia de Vitória/ES - Brazil, an ASM was found in the right inferior limb of a male cadaver fixed in $10 \%$ formalin. This supernumerary muscle was $3 \mathrm{~cm}$ wide, $9 \mathrm{~cm}$ long and $1 \mathrm{~cm}$ thick in its most voluminous part, in typical penniform fibers arrangement. It was located in the posteromedial region of the ankle, anterior to the Achilles tendon and posterior to the deep muscles of the leg compartment. Its anterior face covered the tibial nerve and the posterior tibial vessels, while its lower half was covered by the flexor retinaculum into the tarsal tunnel. Reports in the literature show possible compression of a neurovascular bundle because of its intimal position within the tarsal tunnel, which could result in ischemic compartment syndrome.
\end{abstract}

Keywords: Anatomic variation; Muscle, Skeletal; Ankle.

\section{INTRODUCTION}

Supernumerary muscles in the leg and foot can cause discomfort and impairment of joint function; thereby assuming clinical and surgical relevance.

Although Cruveilhier first described the accessory soleus muscle (ASM) in 1843, ${ }^{1,2}$ since then the number of published cases has remained scarce. The incidence of this anatomical variation is estimated to occur in $0.5-6 \%$ of the general population. ${ }^{3}$

This congenital anatomical variation may be unilateral or bilateral, and when symptomatic, the complaints are confined to the malleolar region. ${ }^{4}$ The paucity of data in the literature is due to asymptomatic cases, which are consequently not reported. The recent reports on the presence of ASM are associated with tarsal tunnel syndrome, a painful

\footnotetext{
a Departamento de Morfologia - Universidade Federal do Espírito Santo, Vitória/ES - Brazil.

b Setor de Anatomia - Escola Superior de Ciências da Santa Casa de Misericórdia de Vitória, Vitória/ES - Brazil.
}

Copyright $\odot 2013$ Autopsy and Case Reports - This is an Open Access article distributed of terms of the Creative Commons Attribution NonCommercial License (http://creativecommons.org/licenses/by/3.0/) which permits unrestricted non-commercial use, distribution, and reproduction in any médium provided article is properly cited. 
foot entity secondary to tibial nerve compression. ${ }^{5}$ Thus, the medical implications of ASM justified the current research, since the recognition of this variation is important to the surgical practice of the ankle and foot, ${ }^{6}$ especially after the extensive inclusion of minimally invasive surgical techniques. ${ }^{7}$

In contrast, there is a gap of knowledge regarding the presenting forms of this anatomical variation in the literature. The differential diagnosis with lipoma, hemangioma, synovioma, and myosarcoma of the posterior region of the malleolus medialis ${ }^{2,8}$ has to be considered.

Thus, the aim of this article is to describe in detail the presence of ASM in a cadaver, using the anatomical dissection technique.

\section{CASE REPORT}

An accessory soleus muscle was found during a routine dissection to study the right lower limb and tarsal tunnel. This finding was detected in the right lower limb of a formalin-fixed male cadaver belonging to the anatomical collection of the Laboratory of Anatomy of the Escola Superior de Ciências da Santa Casa de Misericórdia de Vitória/ES - Brazil, and the following description was approved by the Institutional Ethics Committee.

The ASM has its proximal insertion in the middle third of the tibia, anterior to the soleus muscle by a thickening of its fascia, which formed a laminar tendon (Figure 1).

From its proximal origin, the muscle showed an oblique orientation toward the malleolus medialis. The ASM did not receive any fiber from the soleus muscle assuming the shape of a typical penniform muscle (Figure 2).

The morphometry revealed the ASM was $3 \mathrm{~cm}$ wide, $9 \mathrm{~cm}$ long and $1 \mathrm{~cm}$ thick in its widest section (Figure 3 ), becoming thinner towards the tendon ends.

The supernumerary muscle was located in the posteromedial region of the ankle anteriorly to the calcaneal tendon and posteriorly to the medial malleolus, flexor digitorum longus, tibialis posterior, and flexor hallucis longus muscles. Its anterior face covered the posterior face of the tibial nerve, as well

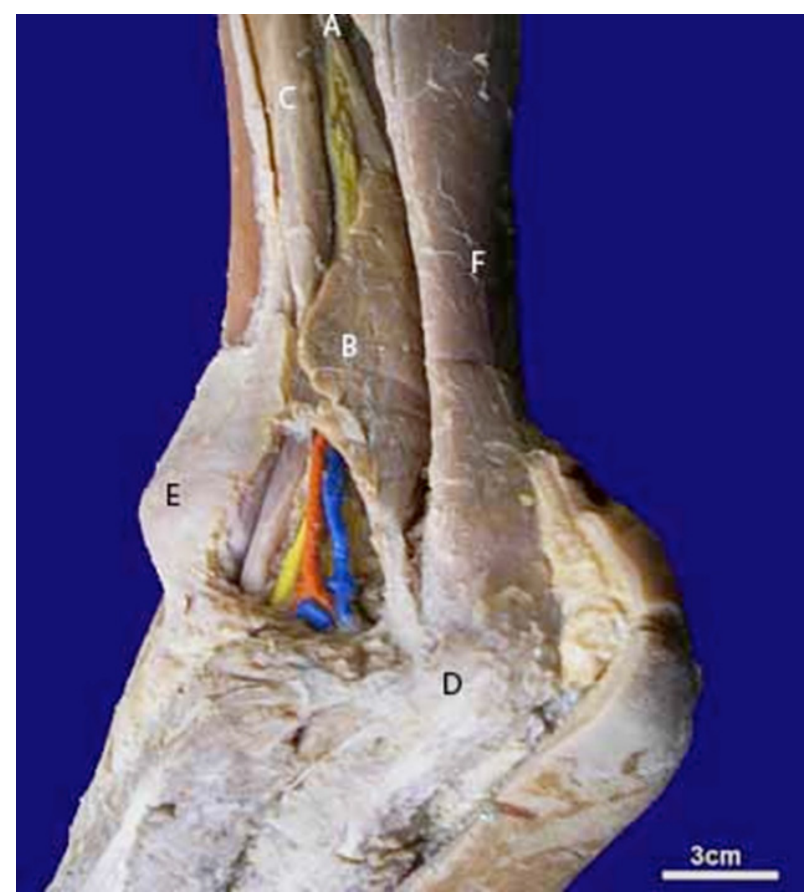

Figure 1 - Medial view of the right ankle showing at point $\mathbf{A}$ - the origin of ASM; $\mathbf{B}$ - ASM; $\mathbf{C}$ - flexor digitorum longus muscle; D - calcaneus; $\mathbf{E}$ - medial malleolus; and $\mathbf{F}$ - calcaneal tendon.

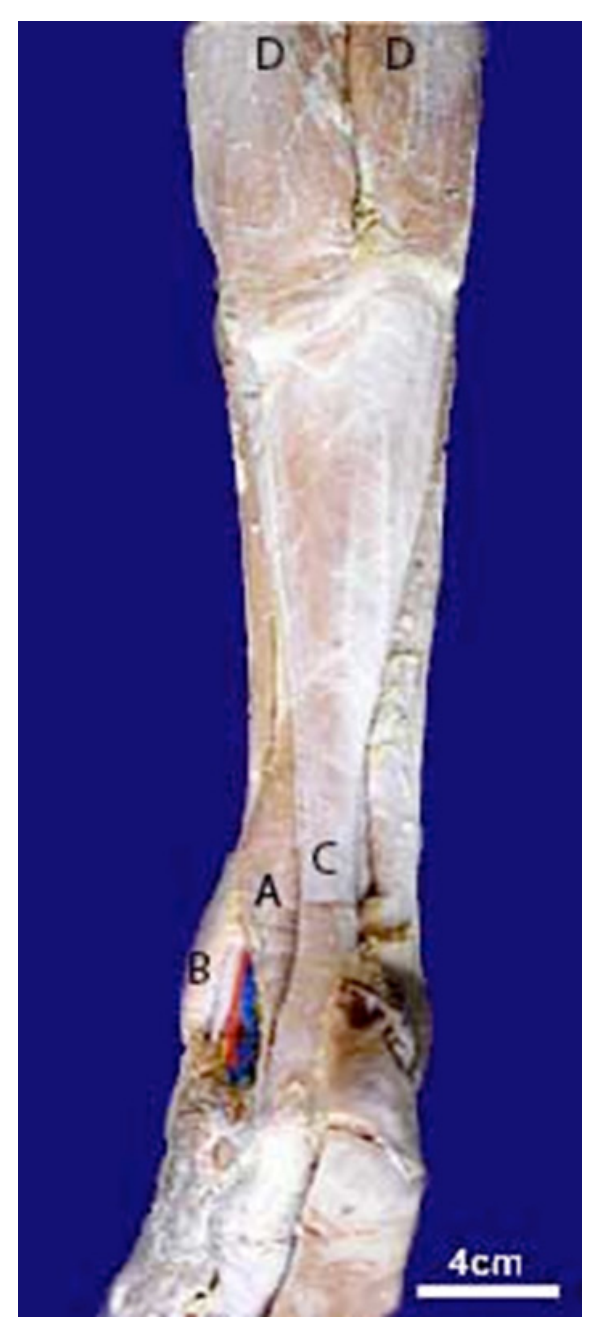

Figure 2-Posterior view of the right leg showing at point A - ASM; B - medial malleolus; C - calcaneal tendon; and $\mathbf{D}$ - gastrocnemius muscles. 


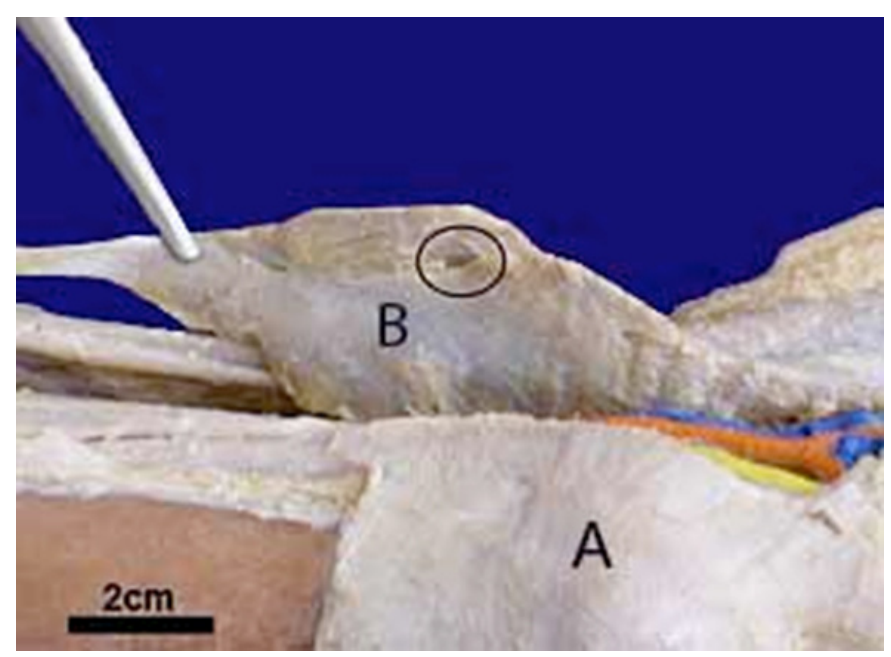

Figure 3-Anterior view of the ASM showing at point B - muscular fibers in a penniform arrangement, obliquely inserting in the soleus muscle tendon; and A - medial malleolus; the circle indicates the location of the muscle's arterial supply.

as the posterior tibial artery and veins, keeping these structures between the ASM (posteriorly) and the posterior face of the medial malleolus (anteriorly). The ASM posterior face was fully related with the calcaneal tendon, and its lower portion was covered by the flexor retinaculum of the ankle into the tarsal tunnel (Figure 4).

The distal insertion of this muscle was fixed on the medial surface of the calcaneus about 1 $\mathrm{cm}$ anterior and inferiorly the calcaneal tendon (Figure 4 ), by a rounded and short tendon, more robust than the muscle origin.

Moreover, as a posterior compartment muscle of the leg, its innervation was made by a muscular branch of the tibial nerve, and its arterial supply was derived from a branch of the posterior tibial artery, which dipped into the muscle in the upper third of its anterior face (Figure 3 ).

Due to its characteristics and the topography of the fasteners in the leg and foot, it is believed that the contraction of the ASM is able to help the inversion and plantar flexion (Figure 5).

\section{DISCUSSION}

Unilateral ASM in the retromalleolar region was found, and its topographic relationships were thoroughly revealed using anatomy dissection techniques.

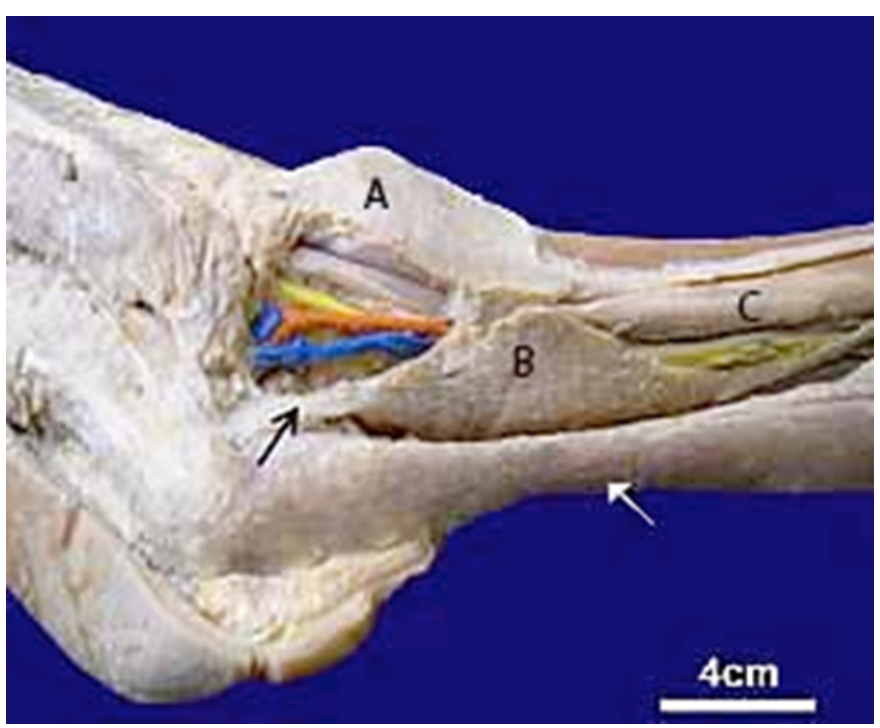

Figure 4 - Relationship of the ASM with the tarsal tunnel structures showing at point $\mathbf{A}$ - medial malleolus; $\mathbf{B}$ - ASM; and C - flexor digitorum longus muscle; (white arrow) calcaneal tendon; (black arrow) insertion tendon of the ASM; (blue) posterior tibial veins; (orange) posterior tibial artery; and (yellow) tibial nerve.

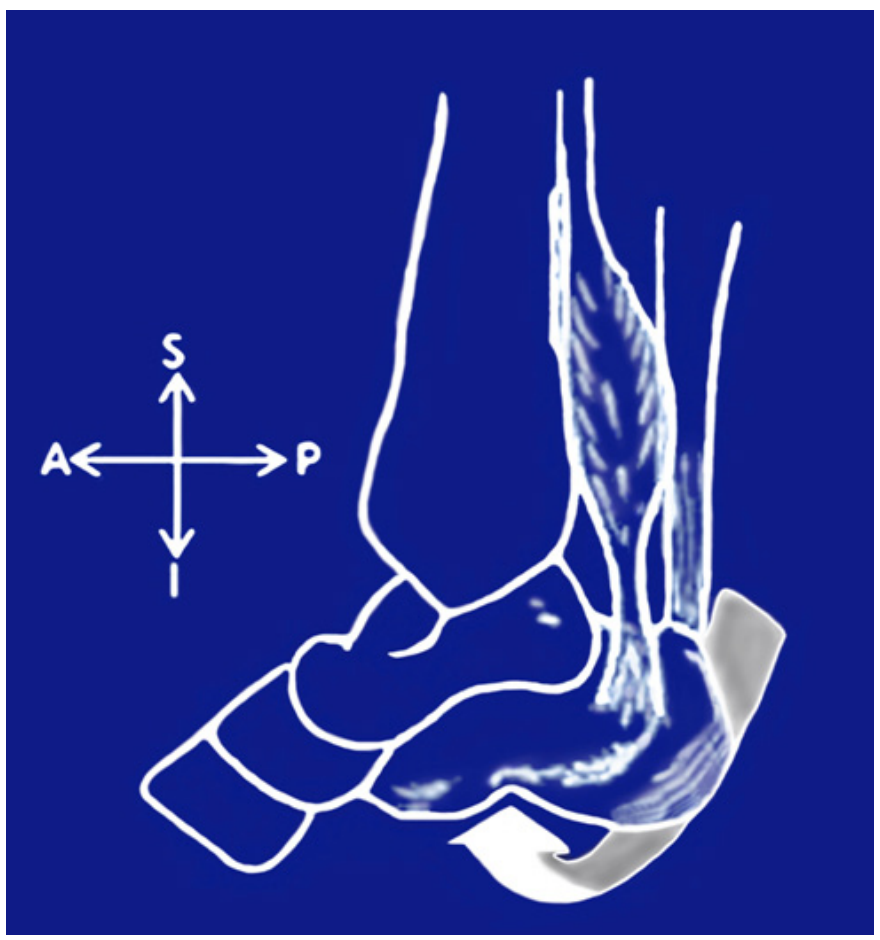

Figure 5 - Schematic illustration of the ASM action. $S=$ superior; $I=$ inferior; $A=$ anterior; $P=$ posterior.

The ASM observed in this report confirm other authors' findings, ${ }^{4,9-11}$ both in the origin and insertion of the supernumerary muscle. Five types of insertions have been described for this supernumerary muscle; namely: (1) insertion along the calcaneal tendon; (2) tendinous insertion on the superior calcaneal surface; (3) direct muscular 
insertion on the superior calcaneal surface; (4) direct muscular insertion on the medial calcaneal surface; and (5) tendinous insertion on the medial calcaneal surface.

ASM can share the blood supply and innervation with the soleus muscle, or the neurovascular provision may be independent. ASM may be unilateral or bilateral according to $\mathrm{Yu}$ and Resnick $^{12}$ descriptions. Our case of ASM presented the type 5 insertion; that is, a tendinous insertion on the calcaneus medial face. With a careful dissection technique we could see its proximal fixation through the thickening of the soleus muscle fascia. Other authors ${ }^{13,14}$ could not accurately report this data, or document the origin through images.

Surgery of the posterior leg face and deep leg should be carefully studied in order to avoid unnecessary extraction of the ASM, which could increase the muscular volume inside the tarsal tunnel, causing or even worsening the patient's complaints.

Given the topography of the ASM, it is possible to suggest that it plays an important role in the description of clinical syndromes related to the tarsal tunnel, as stated by other authors. ${ }^{2,7,13}$ The presence of this supernumerary muscle in the retromalleolar position may cause tarsal tunnel syndrome, since it can compress the neurovascular bundle within this osteofibrous tunnel. The individual with this anatomical variation may present pain and paresthesia in the foot as well as a limping gait. ${ }^{15}$ Furthermore, the clinical examination may disclose in the ankle region a swelling or a non-pitting edema, even in asymptomatic cases. This description supports the suggestion that the diagnostic assessment of this anatomical variation should be performed by magnetic resonance imaging (MRI), since this is a non-invasive method. ${ }^{12}$

Clinically, it is suggested that the pain is a result of a poor muscular vascularization or is due to ischemic compartment syndrome. Muscular activity increases $20 \%$ of the muscle volume consequently contributing to the elevation of intra-compartment pressure and compression on the posterior tibial artery and tibial nerve. Thus, muscles blood flow is reduced, causing pain. ${ }^{16}$ Unilateral pain in the knee, ankle, and heel, and involuntary movements associated with the second to fifth toe may also be associated with ASM, due to compression of the posterior tibial nerve. ${ }^{17}$ In addition, the detachment and surgical excision of the ASM for the treatment of equinovarus deformity have already been used and show positive outcomes. ${ }^{8}$

In the past, some anatomists have described this variation as a special plantaris muscle,$^{18}$ which could have migrated from their femoral origin to the fascia of the soleus muscle or posterior tibial face. Nevertheless, in this report, the plantaris muscle was found intact, which confirms that this ASM is a supernumerary muscular anatomical variation.

Literature reviews revealed a higher prevalence of this finding among men (58\% of cases). ${ }^{10}$ Although debatable, it may be suggested that the greater number of symptomatic cases are reported in men due to greater muscle trophism and denser muscle fascia among males. This characteristic contributes to narrowing of the tarsal tunnel, increasing the susceptibility of any imbalance between these structures. On the other hand, the number of women who can present ASM, but are asymptomatic, may be related to the use of high-heeled footwear, which shortens every muscle of the leg's posterior compartment, thereby decreasing the compression of the tarsal tunnel and consequent symptoms.

Currently, there is a spread of "problembased learning," which correlates clinical situations with human anatomy. ${ }^{19}$ Examples of such clinical entities involving the compression of neurovascular bundles are carpal tunnel syndrome, ${ }^{20}$ the superior orbital fissure, ${ }^{21,22}$ or adductor canal. ${ }^{19}$ In fact, these clinical entities encourage the study of regional anatomy with professional applications. Thus, the ASM becomes another example of this academic practice in a course of study on compressive syndromes.

\section{REFERENCES}

1. Cruveilhier J. Traité d'anatomie descriptive. 2nd ed. Paris: Béchet jeune; 1843. French.

2. Dunn AW. Anomalousmusclessimulatingsoft-tissue tumorsin thelower extremities. Reportofthreecases. J Bone Joint Surg Am. 1965;47(7):1397-400. PMid:5837639.

3. Peterson DA, Stinson W, Carter J. Bilateral accessory soleus: a report on four patients with partial fasciectomy. Foot Ankle. 1993;14(5):284-8. PMid:8349215. http://dx.doi. org/10.1177/107110079301400509

4. Brodie JT, Dormans JP, Gregg JR, Davidson RS. Accessory soleus muscle. A report of 4 cases and review of literature. 
Clin Orthop Relat Res. 1997;(337):180-6. PMid:9137189. http://dx.doi.org/10.1097/00003086-199704000-00020

5. Arriaza Loureda R, Cantos Melián B, Couceiro González G, Sampedro Curbera C, Aizpurua Prada J. Músculo sóleo accesorio. Rev Ortop Traumatol. 2002;1:63-6 [cited 2013 July 14]. Available from: http://apps.elsevier.es/watermark/ ctl_servlet?_f=10\&pident_articulo=13028225\&pident_ usuario $=0 \&$ pcontactid $=\&$ pident_revista $=129 \&$ ty $=77 \&$ acci on=L\&origen=zonadelectura\&web=http://zl.elsevier.es\&la $\mathrm{n}=$ es\&fichero=129v46n01a13028225pdf001.pdf. Spanish.

6. John MM, Borrelli AH. Asymptomatic accessory soleus muscle. J Foot Ankle Surg. 1999;38(2):150-3. http://dx.doi. org/10.1016/S1067-2516(99)80029-5

7. Bezerra MJC, Leite JAD, Estrela JE N ${ }^{\circ}$, Romero S. Liberação do túnel do tarso pela técnica endoscópica: uma proposta de acesso cirúrgico. Acta Ortop Bras. 2005;13(1):46. Portuguese. http://dx.doi.org/10.1590/S1413-78522005000100012

8. Bonnell J, Cruess RL. Anomalous insertion of the soleus muscle as a causes of fixed equinus deformity. A case report. J Bone Joint Surg Am. 1969;51(5):999-1000. PMid:5793857.

9. Vanek J, Fourré D. Accessory soleus muscle. Acta Orthop Belg. 1993;59(4):401-3. PMid:8116375.

10. Hatzantonis C, Agur A, Naraghi A, Gautier S, McKee N. Dissecting the accessory soleus muscle: A literature review, cadaveric study, and imaging study. Clin Anat. 2011;24(7):90310. PMid:21538570. http://dx.doi.org/10.1002/ca.21188

11. Testut L. Les anomalies musculaires chez l'homme: expliquées par l'anatomie comparée leur importance en anthropologie [Internet]. Paris: G. Masson; 1884 [2013 July 15]. Available form: http://ia600307.us.archive.org/30/items/ lesanomaliesmusc00testuoft/lesanomaliesmusc00testuoft. pdf French.

12. Yu JS, Resnick D. MR imaging of the accessory soleus muscle appearance in six patients and a review of the literature. Skeletal Radiol. 1994;23(7):525-8. PMid:7824980. http://dx.doi.org/10.1007/BF00223083

13. Singh S, Suri RK, Mehta V, Loh H, Arora J, Rath G. Bilateral additional bellies of the soleus muscle: anatomical and clinical insight. Int J Anat Var. 2009 [cited 2013 July 15];2:20-2. Available from: http://www.ijav.org/2009/ijav_09_020-022.pdf

14. Reis FP, Aragão JA, Fernandes AC, Feitosa VL, Fakhouri R, Nunes MA. The accessory soleus muscle: case report and a review of the literature. Int J Morphol. 2007;25(4):881-4. http://dx.doi.org/10.4067/S0717-95022007000400032

15. Doda N, Peh WCG, Chawla A. Symptomatic accessory soleus muscle: diagnosis and follow-up on magnetic resonance imaging. Br J Radiol. 2006;79(946):e129-32. PMid:16980668. http://dx.doi.org/10.1259/bjr/83389292

16. Leswick DA, Chow V, Stoneham GW. Resident's corner. Answer to case of the month\# 94. Can Assoc Radiol J. 2003;54(5):313-5. PMid:14689808.

17. Pla ME, Dillingham TR, Spellman NT, Colon E, Jabbari B. Painful legs and moving toes associates with tarsal tunnel syndrome and accessory soleus muscle. Mov Disord. 1996;11(1):82-6. PMid:8771072. http://dx.doi.org/10.1002/ mds.870110115

18. Frohse F, Frankel M. Die muskeln des menschlichen beines. Jena: Fischer; 1913. German.

19. Oliveira F, Vasconcellos Fontes RB, Silva Baptista J, Mayer WP, Campos Boldrini S, Liberti EA. The connective tissue of the adductor canal--a morphological study in fetal and adult specimens. J Anat. 2009;214(3):388-95. PMid:19245505 PMCid:PMC2673789. http://dx.doi.org/10.1111/j.14697580.2009.01047.x

20. Scalco RS, Pietroski F, Celli LFS, Gomes I, Becker J. Seasonal variation in prevalence of carpal tunnel syndrome. Muscle Nerve. 2013;47(6):925-7. http://dx.doi.org/10.1002/ mus.23754

21. Zachariades N, Vairaktaris E, Papavassiliou D, Papademetriou I, Mezitis M, Triantafyllou D. The superior orbital fissure syndrome. Journal Maxillofac Surg. 1985;13:125-8. http:// dx.doi.org/10.1016/S0301-0503(85)80031-X

22. Gabikian P, Chowdhary AM, Kott B, Lazar DA, Britz GW. Isolated superior orbital fissure syndrome resulting from gunshot wound to the head. Curr Probl Diagn Radiol. 2012 Jul;41(4):112-3. http://dx.doi.org/10.1067/j. cpradiol.2011.07.012

\section{Conflict of interest: None}

Submitted on: $16^{\text {th }}$ July 2013

Accept on: $15^{\text {th }}$ September 2013

Correspondence: Setor de Anatomia

Escola Superior de Ciências da Santa Casa de Misericórdia de Vitória

Av. N. Sra. Da Penha, 2190 - Santa Luiza - Vitória/ES - Brazil

CEP: 29045-402 - Phone: +55 (27) 33343546

E-mail: william.mayer@emescam.br 
